\section{Mariusz Puchacz}

Wydział Historyczno-Socjologiczny

Uniwersytet w Białymstoku
BlAŁOSTOCKIE

TEKl

HISTORYCZNE

TOM 16/2018

ISSN 1425-1930

DOI: $10.15290 /$ bth.2018.16.04

\title{
Imigracja na Hawaje z Japonii w latach 1885-1900
}

Hawaje, archipelag położony na Pacyfiku, najmłodszy stan USA, jest powszechnie znany i ceniony ze względu na swoje walory turystyczne. Niektórzy kojarzą go zapewne również z japońskim atakiem na amerykańską bazę Pearl Harbor, który rozpoczał wojnę na Pacyfiku. Hawaje długo pozostawały dla świata zachodniego terra incognita. Ten stan rzeczy zmienił się dopiero w $1778 \mathrm{r}$. za sprawą angielskiego żeglarza i odkrywcy Jamesa Cooka, a odkrycie archipelagu było źródłem procesów, które całkowicie zmieniły jego oblicze.

Wśród tych najważniejszych na szczególną uwagę zasługują dwa. Pierwszym z nich jest depopulacja Hawajów. Ich rdzenni mieszkańcy okazali się być - podobnie jak Indianie obu Ameryk - zupełnie nieodporni na choroby przywleczone przez białych. W konsekwencji ich liczebność spadała w szybkim tempie. $\mathrm{W}$ przeciągu stu lat z kilkuset do zaledwie kilkudziesięciu tysięcy ${ }^{1}$. Drugim procesem kluczowym dla dziejów Hawajów było przejmowanie wpływu na losy archipelagu przez mocarstwa oraz ich poddanych i obywateli osiedlających się na tym obszarze. Początkowym efektem była wprawdzie konsolidacja władzy na Hawajach przez króla Kamehamehę $\mathrm{I}^{2}$, jednak wraz z upływem czasu jego następcy tracili realną władzę do tego stopnia, iż w ostatniej dekadzie XIX w. musieli się pogodzić z kresem istnienia własnego państwa.

Początkowo Hawaje znalazły się w orbicie wpływów Wielkiej Brytanii, co do dzisiaj znajduje odbicie we fladze stanu Hawaje, w której lewym górnym rogu widnieje Union Jack. Historycy mają pewne wątpliwości co do istoty relacji hawajsko-brytyjskich, jednak dominacja Londynu nad archipelagiem pod koniec XVIII i w pierwszych dekadach XIX w. nie powinna budzić wątpliwości³

1 E. C. Nordyke, The Peopling of Hawai'i, Honolulu 1989 [1977], rozdz. II.

2 R. S. Kuykendall, The Hawaiian Kingdom, t. I: 1778-1854. Foundation and Transformation, Honolulu 1965 [1938], rozdz. III.

3 Zob. R. E. A. Hackler, Alliance or Cession? Missing Letter from Kamehameha I to King George III of England Casts Light on 1794 Agreement, „Hawaiian Journal of History” (dalej: HJH) 1986, t. 20, s. 1-14. 
Nie było to jednak podporządkowanie całkowite, a na Hawajach krzyżowały się wpływy innych państw, swoje piętno odcisnęły także przedsiębiorcze jednostki ${ }^{4}$.

Po kilkudziesięciu latach pozycję Wielkiej Brytanii względem Królestwa Hawajów przejęły Stany Zjednoczone. Zainteresowanie Waszyngtonu tym archipelagiem miało podłoże czysto ekonomiczne. Początkowo było związane z eksploatacją drzewa sandałowego, a od lat 30. XIX w. z dynamicznie rozwijającym się wielorybnictwem. Ponieważ łowiska na północnym Atlantyku zostały gruntownie przetrzebione, przemysłowcy z amerykańskiej Nowej Anglii przenieśli swoje statki na Pacyfik. Hawaje zwróciły ich uwagę, ponieważ były położone wprost idealnie: 40 dni żeglugi do Japonii, 30 dni do Alaski i zaledwie 15 dni do Zatoki Kalifornijskiej. W krótkim czasie Honolulu i Lahaina stały się dla ogromnej liczby statków zawijających do ich portów źródłem zaopatrzenia i „rozrywki”. Tylko między latami 1845 a 1854 na Hawaje zawinęły 4402 amerykańskie statki wielorybnicze. W tym samym czasie z hawajskich portów skorzystało zaledwie 405 statków pływających pod banderą inną niż amerykańska5.

Znaczenie jakie archipelag miał wówczas dla amerykańskiego przemysłu wielorybniczego, w połączeniu $\mathrm{z}$ prowadzoną na jego obszarze działalnością amerykańskich misjonarzy (tyleż religijną co polityczną i gospodarczą) szybko skłoniło waszyngtońskich polityków do włączenia Hawajów w ramy amerykańskiej strefy wpływów. Stało się tak za sprawą sformułowanej w 1842 r. przez administrację prezydenta Johna Tylera doktryny polityki USA wobec Hawajów, która od nazwiska prezydenta znana jest jako doktryna Tylera.

Według jednego z historyków, była ona początkiem dominacji kolonialnej Stanów Zjednoczonych nad Hawajami (The Policy of the United States Colonial Domination), po której sformułowaniu wszystkie umowy zawierane pomiędzy Królestwem Hawajów a Stanami Zjednoczonymi były korzystniejsze dla interesów tego państwa niż dla Hawajczyków6. W istocie doktryna Tylera wzywała Francję i Wielką Brytanię do poszanowania niepodległości Hawajów, co miało zabezpieczyć amerykańskie interesy gospodarcze w tym królestwie. Rok 1842 stanowi ważną cezurę w dziejach amerykańskiej ekspansji na Hawajach? . Wielka Brytania częściowo zaakceptowała stanowisko zajęte przez administrację Tylera, a w rezultacie powiększającej się z upływem czasu przewagi

\footnotetext{
4 Prywatnym przedsięwzięciem była próba podporządkowania Hawajów Rosji przez niemieckiego awanturnika Georga Schäffera pracującego dla Kompanii Rosyjsko-Amerykańskiej. Zob. R. A. Pierce, Georg Anton Schäffer, Russia's Man in Hawaii, 1815-1817, „Pacific Historical Review" (dalej: PHR) 1963, t. 32, nr 4, s. 397-405.

5 N. J. Kent, Hawaii: Islands under the Influence, New York 1983, s. 21-22.

${ }^{6}$ H-K. Trask, From a Native Daughter. Colonialism and Sovereignty in Hawai'i, Honolulu 1999 [1993], s. 217.

7 Co znalazło odzwierciedlenie w ważnej pracy amerykańskiego historyka S. K. Stevensa, American Expansion in Hawaii, 1842-1898, New York 1945.
} 
wpływów USA, poszanowanie formalnej niepodległości królestwa stało się podstawą jej polityki ${ }^{8}$.

W następnych dekadach wpływy USA zostały ugruntowane, podobnie jak pozycja Amerykanów i Europejczyków (określanych jako haole) zamieszkujących Królestwo Hawajów. W praktyce stworzyli oni białą oligarchię, która uzyskała bardzo duży wpływ na politykę tego państwa. Podstawą ich wpływów i bogactwa było rolnictwo, w szczególności uprawa trzciny cukrowej. Stała się ona w miejsce wielorybnictwa podstawą gospodarki Hawajów w latach 60. XIX w., choć uprawiana była znacznie wcześniej. Stworzenie potężnych przedsiębiorstw możliwe było dzięki kilku aktom prawnym z lat 1848-1850. Na mocy jednego z nich dokonano podziału ziemi uprzednio należącej do króla. Choć intencją Kamehamehy III było zabezpieczenie posiadania ziemi przez jego rodaków, efekt okazał się całkowicie odwrotny od zamierzonego. Z ponad 1,5 mln akrów ziemi w ręce Hawajczyków trafiło niespełna 29 tys. Pozostała część została wystawiona na sprzedaż. Prawo zakupu oprócz rdzennych mieszkańców archipelagu posiadali również cudzoziemcy, którzy wykupili większość ziemi. Wymowny jest przykład sprzedaży jednemu z nich całej wyspy Nihau o powierzchni 61 tys. akrów ${ }^{9}$. Podstawę prawną zatrudniania robotników na plantacjach dostarczył $M a$ sters and Servants Act of 1850, wprowadzający w królestwie Hawajów system pracy kontraktowej. Zawierana na kilka lat umowa pomiędzy pracodawcą a pracownikiem ściśle regulowała warunki pracy. Ucieczka z plantacji czy uchylanie się od pracy skutkowało karami. Teoretycznie prawo nie pozostawiało robotnika na pastwę losu. W różnych sytuacjach przewidywało karę także dla pracodawcy, zaś używanie przemocy miało skutkować rozwiązaniem kontraktu ${ }^{10}$.

Hawajscy plantatorzy mieli korzystny system prawny, władzę, pieniądze i bezcłowy dostęp do ogromnego amerykańskiego rynku zagwarantowany na mocy traktatu o wzajemności zawartego w 1875 r. między Hawajami a USA. Brakowało im tylko robotników - najlepiej w postaci taniej siły roboczej - dzięki którym możliwe byłoby powiększanie areału plantacji i wzrost produkcji cukru. Roli tej nie mogli spełnić rdzenni mieszkańcy archipelagu, zaś napływ ludności białej był zbyt mały. Poza tym ciężka praca na plantacji trzciny cukrowej nie była dla nich szczególnie kuszącą perspektywą, zwłaszcza dlatego, że zarobki w Stanach Zjednoczonych były większe.

Problem braku odpowiedniej liczby rąk do pracy był niemalże stałą cechą gospodarki Hawajów. W tej sytuacji oczy plantatorów zwróciły się na Daleki Wschód w stronę Chin. Imigranci z tego kraju byli częścią mozaiki etnicznej Hawajów praktycznie od momentu ich odkrycia przez Cooka. To Chińczyk Wong Tze-Chun w 1802 r. uruchomił pierwszą hawajską cukrownię. Ponieważ Chiń-

8 Zob. M. Tate, Great Britain and the Sovereignty of Hawaii, PHR 1962, t. 31, nr 4, s. 327-348.

9 J. M. Van Dyke, Who Owns the Crown Lands of Hawai'i?, Honolulu 2008, s. 48, 57.

10 E. D. Beechert, Working in Hawaii: A Labor History, Honolulu 1985, s. 41 i in. 
czycy byli znani jako solidni i pracowici robotnicy zdecydowano się na sprowadzenie większej ich liczby do pracy na plantacjach. Pierwsza grupa przybyła w $1852 \mathrm{r}^{11}$

Po pewnym czasie Chińczycy narazili się jednak na krytykę ze strony władz hawajskich. Król Kamehameha III był zdania, że nie wykazywali żadnej chęci asymilacji z rdzenną ludnością. Do tego po pewnym czasie doszły zarzuty o sprowadzanie przez Chińczyków na Hawaje chorób ${ }^{12}$. Fascynacja imigracją chińską była więc stosunkowo krótka, a za lekarstwo na bolączki hawajskiego rolnictwa uznano Japończyków. Zadanie ich sprowadzenia powierzono konsulowi generalnemu w Jokohamie, Amerykaninowi Eugenowi Van Reedowi.

Stanął on przed bardzo trudnym zadaniem. Pomimo otwarcia Japonii na świat przez misję Matthew Perry'ego w 1854 r., emigracja zarobkowa mieszkańców nie została zalegalizowana. Kraj opuszczali niemal wyłącznie politycy, dyplomaci czy studenci. Mimo to Reedowi w 1868 r. udało się uzyskać zgodę na opuszczenie kraju przez 350 osób. Problem tkwił jednak w tym, że otrzymał ją od urzędników szoguna, w trakcie przegrywanej przez niego wojny z cesarzem. Nowy gubernator Jokohamy był wprawdzie skłonny zaakceptować emigrację robotników do pracy na plantacjach trzciny cukrowej, jednak dopiero po udzieleniu dodatkowej gwarancji. Reed nie tylko odmówił, ale w dodatku zdecydował się na wysłanie robotników bez zgody cesarskich władz. Doprowadził tym do skandalu, który mógł mieć poważne konsekwencje przede wszystkim dla niego samego. Wściekli Japończycy domagali się głowy Reeda, który choć kary ostatecznie uniknął, to obawiając się skazania przez amerykański sąd konsularny wystąpił o obywatelstwo Hawajów. Na archipelag dotarło 149 osób, określanych jako Gannen Mono, tzn. Ludzie Pierwszego Roku. Nazwa wynika z faktu, iż opuścili Japonię w pierwszym roku panowania cesarza Meiji ${ }^{13}$.

Kontrowersje wywołane działaniami Reeda zostały zażegane w rezultacie japońskiej misji na Hawaje, która doprowadziła do powrotu blisko 40 robotników przed ukończeniem trzyletniego kontraktu, który odpracować zobowiązał się każdy z Japończyków przybyłych do pracy na plantacjach. W 1871 r. doszło nawet do podpisania traktatu japońsko-hawajskiego, który teoretycznie legalizował emigrację zarobkową z Japonii ${ }^{14}$. W praktyce $\mathrm{z}$ powodu niechęci władz japońskich, Gannen Mono pozostali jedyną grupą robotników jaka przybyła na Hawaje do połowy lat 80. XIX w.

11 E. C. Nordyke, op. cit., s. 52-54; E. C. Nordyke, R. K. C. Lee, The Chinese in Hawai' $i$ : A Historical and Demographic Perspective, HJH 1989, t. 23, s. 196-200.

12 E. C. Nordyke, op. cit., s. 54-55.

13 H. Conroy, Japanese Expansion into Hawaii, 1868-1898, San Francisco 1973 [1949], rozdz. 3; M. Marumoto, ,First Year” Immigrants to Hawaii \& Eugen Van Reed, [w:] East Across the Pacific. Historiological \& Sociological Studies of Japanese Immigration \& Assimilation, ed. by H. Conroy, T. S. Miyakawa, Santa Barbara and London 1972, s. 5-25.

$14 \mathrm{Na}$ ten temat szeroko, H. Conroy, op. cit., rozdz. 4-5. 
Tokio sprzeciwiało się emigracji zarobkowej przede wszystkim z obawy, by wykonujący najniżej płatne prace japońscy robotnicy nie pogorszyli wizerunku państwa w oczach Europejczyków i Amerykanów oraz nie podzielili losu swoich chińskich odpowiedników. Emigracja Chińczyków często była postrzegana przez międzynarodową opinię publiczną jako rodzaj handlu niewolnikami. Amerykanie i Brytyjczycy byli przeczuleni na tym punkcie. Japońscy politycy wiedzieli o tym co najmniej od czasu sprawy peruwiańskiego statku „Maria Luz” przybyłego do Jokohamy w 1872 r. Wówczas dyplomaci amerykańscy i brytyjscy wzywali Japonię do interwencji na rzecz przetrzymywanych na nim i źle traktowanych, a uprzednio w wielu przypadkach porwanych Chińczyków ${ }^{15}$. Po wielu latach agitacji, w 1882 r. Kongres Stanów Zjednoczonych uchwalił ustawę, która zakazywała wpuszczania Chińczyków do tego kraju. Utożsamienie imigrantów japońskich $\mathrm{z}$ chińskimi i w konsekwencji potraktowanie ich w podobny sposób byłoby uderzeniem w honor dumnego narodu i prestiż państwa japońskiego. Byłaby to zarazem przeszkoda $\mathrm{w}$ osiągnięciu najważniejszego celu politycznego Japonii, jakim była rewizja nierównoprawnych traktatów. Strach przed takim scenariuszem był stale obecny wśród japońskich elit, które naśladując mocarstwa zachodnie same zaczęły kształtować relacje z Koreą i Chinami z pozycji siły. Już w 1876 r. Japonia narzuciła tej pierwszej traktat nierównoprawny, co jednoznacznie wskazuje, że nie była ona przeciwna dominacji mocarstw w polityce międzynarodowej. Problem tkwił jedynie w tym, że chciała być jednym z nich. Wspólnota losu z Chińczykami i innymi podporząakowywanymi i dyskryminowanymi Azjatami była zatem wykluczona ${ }^{16}$.

Rząd japoński zmienił swoje stanowisko w sprawie emigracji robotników dopiero pod wpływem niepokojów społecznych będących skutkiem pogarszającego się położenia rolników. Byli oni grupą, która bardzo mocno - poza samurajami może najmocniej - odczuła dynamiczną modernizację. Wymagała sporych nakładów finansowych, co wiązało się z koniecznością zreformowania finansów. Japonia była w tym zakresie ograniczona zawartą z mocarstwami w $1866 \mathrm{r}$. konwencją, która regulowała na jej niekorzyść wysokość ceł importowych i eksportowych ${ }^{17}$. Z tego powodu władze państwowe musiały znaleźć inne źródło stałych wpływów do budżetu.

15 I. G. Saveliev, Rescuing the Prisoners of „Maria Luz”: the Meiji Government and the "Coolie Trade', 1868-1875, [w:] Turning Points in Japanese History, red. B. Edström, London and New York 2013 [2002], s. 71-81.

16 Zarys japońskiej polityki zagranicznej w latach siedemdziesiątych i osiemdziesiątych: I. Nish, Japanese Foreign Policy, 1869-1942. Kasumigaseki to Miyakezaka, London and New York 2010 [1977], rozdz. 1-2; J. Polit, Japońska polityka zagraniczna 1895-1945, Kraków 2015, s. 21-27.

17 Treść konwencji celnej w: Treaties and Conventions, Concluded Between Empire Of Japan and Foreign Nations, Together with Regulations and Communications, 1854-1874, Tokio 1874, s. $249-280$. 
W 1873 r. przeprowadzono reformę podatku ziemskiego. Od tej pory miał on być płacony przede wszystkim pieniędzmi w wysokości odpowiadającej $3 \%$ wartości posiadanej ziemi, niezależnie od osiąganych zbiorów. Nowe prawo było mniej korzystne dla rolników niż wcześniej obowiązujące. W połączeniu z innymi reformami, jak wprowadzenie powszechnej służby wojskowej, doprowadziło do licznych protestów na wsi, także zbrojnych. W rezultacie już w 1877 r. rząd zdecydował się na obniżenie podatku do 2,5\%. Sytuacja na wsi jednak nie uspokoiła się z powodu deflacyjnej polityki realizowanej przez premiera Masayoshi Matsukatę, której skutkiem był duży spadek cen produktów rolnych. Podczas, gdy w 1881 r. cena 1 koku (180 litrów) ryżu wynosiła 14,4 jenów, na początku 1884 r. już tylko 4,6 jena. Japonią wstrząsnęła plaga bankructw rolników, szczególnie tych obciążonych zobowiązaniami kredytowymi. Liczba zbankrutowanych gospodarstw wzrosła z 33 tys. w 1883 r., do 108 tys. w $1885^{18}$.

$\mathrm{Z}$ tego, że społeczeństwo było nazbyt obciążone podatkami zdawały sobie sprawę nie tylko japońskie elity, ale także postronni obserwatorzy, jak choćby były amerykański prezydent i bohater wojny secesyjnej, gen. Ulysses Grant. W trakcie swojego pobytu w Japonii w 1879 r., podczas rozmowy z cesarzem wyraził on opinię, iż środkiem zaradczym jest podniesienie ceł ${ }^{19}$. Jego ocena zależności pomiędzy konwencją celną a japońskim systemem podatkowym była słuszna, jednak Tokio bez zgody mocarstw nic w tej sprawie nie mogło zrobić. Rząd był zmuszony poszukać innego remedium na trudną sytuację panującą na wsi.

W czasie gdy w Japonii narastało oburzenie społeczne wobec nadmiernych obciążeń podatkowych, Hawaje w dalszym ciągu zmagały się $\mathrm{z}$ brakiem robotników. Był to problem niemal nieustannie spędzający plantatorom sen z powiek. W pierwszej połowie lat 80. XIX w. został on częściowo rozwiązany dzięki nieoczekiwanemu i masowemu napływowi Chińczyków. Tylko wiosną 1883 r., w ciągu zaledwie 6 tygodni, na 7 statkach przybyło ich $3400^{20}$. Podczas gdy dla plantatorów byli oni wybawieniem z kłopotów, w opinii premiera Hawajów Williama Murraya Gibsona byli ich źródłem. Postrzegał on bowiem masową imigrację chińską, złożoną niemal wyłącznie z mężczyzn, w dodatku chętnie opuszczających plantacje po upłynięciu kontraktu i słabo asymilujących się z rdzennymi Hawajczykami, za zagrożenie. Dlatego dążył do ograniczenia i kontrolowania napływu Chińczyków. W swoich kalkulacjach Gibson

\footnotetext{
18 S. Vlastos, Opposition Movements in Early Meiji, 1868-1885, [w:] The Cambridge History of Japan, t. 5: The Nineteenth Century, red. M. B. Jansen, New York 2007 [1989], s. 419-420.

19 Zob. R. T. Chang, General Grant's 1879 Visit to Japan, „Monumenta Nipponica” 1969, t. 24, nr 4, s. 384 .

20 R. S. Kuykendall, The Hawaiian Kingdom, t. 3, 1874-1893, The Kalakaua Dynasty, Honolulu 1967, s. 145.
} 
ważne miejsce przyznawał imigracji japońskiej, która miała stanowić dla nich przeciwwagę $e^{21}$.

Po obu stronach Pacyfiku sytuacja dojrzewała zatem do porozumienia w sprawie imigracji japońskiej. Dla Tokio, oprócz problemów wewnętrznych, istotne znaczenie miała z pewnością także osoba króla Hawajów Kalakaui (panował w latach 1874-1891). Monarcha ten nie tylko należał do zwolenników imigracji japońskiej, ale także poszukiwał w Tokio równowagi dla wpływów amerykańskich. Podczas pobytu w Japonii w 1881 r., w trakcie wyprawy dookoła świata, oprócz prośby o japońskich robotników, przedstawił cesarzowi Meiji dalekosiężny plan współpracy między obu państwami, czy wręcz stworzenia w Azji i na Pacyfiku nowego ładu politycznego. Obejmował on zrzeczenie się przez Hawaje prawa eksterytorialności, małżeństwo siostrzenicy króla Kauilani z jednym $\mathrm{z}$ japońskich książąt oraz stworzenie związku państw leżących na Pacyfiku i w Azji, którego przewodnictwo objęłaby Japonia. Ostatecznie cesarz odrzucił propozycje Kalakaui. Wymówił się nieodpowiednim czasem na realizację takich pomysłów i prawdopodobnym negatywnym stosunkiem Chin wobec przedstawionej inicjatywy. W rzeczywistości projekt hawajskiego króla był nieprzystający do międzynarodowej pozycji Japonii, a próba jego realizacji byłaby równoznaczna z pogorszeniem stosunków z mocarstwami i odsunięciem w czasie rewizji nierównoprawnych traktatów. Mimo to propozycje Kalakaui musiały zostać przyjęte pozytywnie przez Japonię i zarazem wpłynąć na podjęcie decyzji o zezwoleniu na emigrację na Hawaje w późniejszym czasie ${ }^{22}$.

Nie można pominąć również wpływu ideologii na zmianę stanowiska Tokio w sprawie emigracji. Od lat 70. w Japonii dużą popularnością cieszyła się teoria przeludnienia Thomasa Malthusa. W opinii jej zwolenników kraj ten miał mieć zbyt dużo ludności, która w dodatku szybko się zwiększała. Nadwyżka powinna więc zostać skierowana poza granice. Grunt pod podjęcie decyzji o rozpoczęciu masowej emigracji przygotowała również teoria ekspansjonizmu. Japończycy bardzo uważnie obserwowali działania Europejczyków i Amerykanów nie tylko w dziedzinie polityki zagranicznej. Podziwiano ich siłę militarną, ale również gospodarczą i handlową, jak też ich mobilność. Wzywano do naśladowania mocarstw i wkroczenia przez Japonię na drogę ekspansji. Nie oznaczało to jednak koniecznie podbojów nowych terytoriów poprzez konflikty zbrojne. Równie dużą wagę przywiązywano do rozwoju handlu i emigracji, które w ocenie Japończyków były częścią ekspansji państw zachodnich. Były to metody pokojowej

\footnotetext{
21 W jednym z listów Gibson napisał o tym następująco: if the Government are supported in their plans for Immigration of Japanese, I think the Chinese difficulty will be rapidly abated". Ibidem, s. 153.

22 H. Conroy, op. cit., s. 73-76; E. Pałasz-Rutkowska, Cesarz Meiji (1852-1912). Wizerunek wtadcy w modernizowanej Japonii, Warszawa 2012, s. 286.
} 
ekspansji, zresztą Japończycy słów „ekspansja”, „kolonizacja” i „,emigracja” używali zamiennie ${ }^{23}$.

Wszystkie te elementy sprawiły, że kiedy ze strony hawajskiej wyszła kolejna propozycja porozumienia $\mathrm{w}$ sprawie imigracji, tym razem rząd japoński wyszedł jej naprzeciw. W 1885 r. w dwóch transportach (luty i lipiec) na Hawaje przybyło 1615 mężczyzn, 194 kobiety i 122 dzieci. Tokio wyraziło zgodę na opuszczenie przez nich kraju, uprzednio precyzyjnie ustalając warunki ich życia i pracy z rządem Królestwa Hawajów. Zgodnie z nimi robotnicy mieli mieć zapewnioną bezpłatną podróż, zakwaterowanie, wyżywienie, pensję na poziomie 9 dolarów miesięcznie i dostęp do ryżu w cenie nie większej niż 5 centów za funt. Oprócz tego część z nich zgodziła się pracować pół godziny dziennie w zamian za prawo do uprawiania warzyw na ćwierćakrowej działce. Dzień pracy miał wynosić 10 godzin, miało ich być miesiącu 26 . Konwencja o imigracji zawarta 28 stycznia 1886 r. dodawała następne szczegółowe ustalenia. Imigracja miała się odbywać wyłącznie w ramach systemu kontraktowego, kontrakt miał trwać 3 lata. Robotnicy mieli mieć do dyspozycji japońskich lekarzy, tłumaczy i inspektorów. Swobodny dostęp do robotników mieli zapewniony przedstawiciele dyplomatyczni i konsularni Japonii ${ }^{24}$.

Polityka emigracyjna Japonii miała zapewnić poddanym cesarza jak najlepsze warunki życia, pracy i ochronę przed nadużyciami ze strony plantatorów. Takie zabiegi są zupełnie zrozumiałe biorąc pod uwagę nienajlepszą sławę jaką cieszyły się hawajskie plantacje. Była więc ona przynajmniej do pewnego stopnia uzasadniona. Wskutek ewolucji sytemu pracy kontraktowej robotnicy rolni u schyłku istnienia Królestwa Hawajów mogli liczyć na znacznie mniejszą ochronę prawną niż kilka dekad wcześniej25. Działania rządu japońskiego miały także na celu stworzenie sytuacji, w której japońscy robotnicy - choć wykonujący dokładnie tę samą pracę - nie byliby automatycznie łączeni z Chińczykami, do których powszechnie przylgnęła łatka kulisów. Tylko tak można tłumaczyć starania o ograniczenie, a najlepiej zakończenie chińskiej imigracji na Hawaje ${ }^{26}$. W oczach japońskich polityków utożsamianie Japończyków z Chińczykami byłoby istotną porażką wizerunkową. Szczegółowe ustalenie warunków pobytu japońskich robotników na Hawajach było potrzebne również ze względu na konieczność przełamania wewnętrznej opozycji, która sprzeciwiała się emigracji.

\footnotetext{
23 A. Iriye, Pacific Estrangement: Japanese and American Expansion, 1897-1911, Chicago 1994 [1972], s. 18-20.

24 A. Ladenson, The Background of the Hawaiian-Japanese Labor Convention of 1886, PHR 1940, t. 9, nr 4, s. 389-400, przedrukowane w: Kodomo no tame ni-For the Sake of the Children. The Japanese American Experience in Hawaii, red. D. Ogawa, Honolulu 1978, s. 12-19.

25 E. D. Beechert, op. cit., s. 55-57.

26 A. Ladenson, op. cit., s. 14-15.
} 
Jej przedstawiciele wzywali rodaków, by nie wyjeżdżali na plantacje, bo tam staną się niewolnikami ${ }^{27}$.

Decyzję Japonii o zezwoleniu na emigrację zarobkową można postrzegać w kategoriach ekspansji. Japońscy robotnicy mieli być zaopatrywani w produkty pochodzące z ojczyzny, zwolnione od podatków i transportowane przez japońskie kompanie handlowe. Rząd Japonii zaproponował również stworzenie subsydiowanej przez państwo regularnej linii rejsowej na trasie Yokohama-Honolulu i zachęcał rząd Królestwa Hawajów do stworzenia takiej samej na trasie Honolulu-San Francisco ${ }^{28}$. Działania te wykraczają poza zabiegi mające zapewnić godne traktowanie poddanych japońskich.

Przytoczone fakty dowodzą, że motywy, którymi kierowali się japońscy politycy przy podjęciu decyzji o wysłaniu robotników i organizacji ich pobytu na Hawajach były skomplikowane i zarazem powiązane ze sobą. Emigracja ta była dla Japonii szkołą polityki ekspansji oraz przynajmniej częściowo także rozładowywała społeczne niezadowolenie. System imigracyjny stworzony przez konwencję z roku 1886 przetrwał do $1894 \mathrm{r}$. W trakcie tych 10 lat na 26 statkach przybyło na Hawaje ponad 29 tys. Japończyków.

\section{Japońska imigracja na Hawaje w latach 1885-1894}

\begin{tabular}{|c|c|c|}
\hline Rok & $\begin{array}{c}\text { Liczba statków } \\
\text { z japońskimi } \\
\text { imigrantami }\end{array}$ & $\begin{array}{c}\text { Liczba } \\
\text { japońskich } \\
\text { imigrantów }\end{array}$ \\
\hline 1885 & 2 & 1932 \\
\hline 1886 & 1 & 927 \\
\hline 1887 & 1 & 1447 \\
\hline 1888 & 3 & 3287 \\
\hline 1889 & 3 & 3004 \\
\hline 1890 & 4 & 3799 \\
\hline 1891 & 5 & 5854 \\
\hline 1892 & 3 & 3211 \\
\hline 1893 & 3 & 4117 \\
\hline 1894 & 1 & 1491 \\
\hline
\end{tabular}

Źródło: A. Moriyama, The Causes of Emigration: The Background of Japanese Emigration to Hawaii, 1885-1894, w: Labor Immigration Under Capitalism. Asian Workers in the United States Before World War II, red. L. Cheng, E. Bonacich, Berkeley-Los Angeles-London 1984, s. 249, tabela 7.1

\footnotetext{
27 Ibidem, s. 17.

28 Ibidem, s. 15.
} 
Większość japońskich imigrantów była bezrolnymi chłopami lub rolnikami posiadającymi małe działki ziemi ${ }^{29}$. Niebagatelną rolę przy podejmowaniu przez nich decyzji o wyjeździe na Hawaje odgrywały oferowane tam zarobki. Biorąc pod uwagę ówczesny kurs jena do dolara kształtujący się na poziomie 0.85 , oferowana przez plantatorów po podwyżce miesięczna pensja na poziomie 15 dolarów była odpowiednikiem 17,65 jenów. Była to wówczas bardzo duża kwota, znacznie przewyższająca zarobki w Japonii. Dla porównania miesięczna pensja wytwórcy dachówek wynosiła wówczas 7,8 jena, cieśli 6,3 , pracownika wynajmowanego na dzień pracy 4,8 jena. Dysproporcja pomiędzy zarobkami w Japonii a oferowanymi na hawajskich plantacjach tłumaczy, dlaczego do pierwszego wyjazdu na Hawaje zgłosiło się aż 28 tysięcy Japończyków ${ }^{30}$.

Należy jednak podkreślić, że choć motywacja ekonomiczna Japończyków upodabnia ich do emigrantów z Europy trafiających na Wschodnie Wybrzeże USA, były to dwa różne typy emigracji. Europejska była niezorganizowana i oparta na indywidualnej inicjatywie. Japońska bazująca na konwencji była imigracją zorganizowaną i nadzorowaną. Na jej kształt przemożny wpływ wywarł amerykański przedsiębiorca $\mathrm{z}$ licznymi kontaktami w kręgach politycznych i biznesowych Japonii, konsul generalny Królestwa Hawajów w Japonii Robert Walker Irwin. Emigranci nie byli osobami przypadkowymi, lecz wyselekcjonowanymi. Pochodzili w większości z południowo-zachodnich prefektur Hiroshima, Yamaguchi, Fukuoka i Kumamoto, gdzie Irwin, za radą swoich bliskich kolegów, genro i ówczesnego ministra spraw zagranicznych Kaoru Inoue i szefa kompanii Mitsui Takahashiego Masudy prowadził akcję rekrutacyjną̧1.

Nie pomniejszając roli konsula, można przypuszczać, że liczba osób, które zdecydowały się na wyjazd w tych czterech prefekturach oraz w konkretnych miejscowościach, z pewnością nie byłaby tak wysoka, gdyby nie wieści i pieniądze napływające z Hawajów. Na krewnych i sąsiadach musiały zrobić wrażenie przykłady emigrantów takich, jak Iwase Kansuke z Kuke. Po niespełna roku pracy na Hawajach przesłał on swoim rodzicom 129 jenów, czyli kwotę znacznie przewyższającą to, co można było zarobić $\mathrm{w}$ jego rodzinnych stronach w takim samym okresie ${ }^{32}$.

$\mathrm{Na}$ atrakcyjność zarobków jako jeden z kluczowych powodów emigracji z Japonii na Hawaje (i do Stanów Zjednoczonych) badacze wskazywali już na

\footnotetext{
29 Y. Ichioka, The Issei: The World of the First Generation Japanese Immigrants, 1885-1924, New York and London 1988, s. 43.

30 A. Moriyama, The Causes of Emigration: The Background of Japanese Emigration to Hawaii, 1885-1894, [w:] Labor Immigration Under Capitalism. Asian Workers in the United States Before World War II, red. L. Cheng, E. Bonacich, Berkeley-Los Angeles-London 1984, s. 268-269.

31 Y. Irwin, H. Conroy, R. W. Irwin and Systematic Immigration to Hawaii, [w:] East Across the Pacific..., s. 40-55. Koncern Mitsui był zaangażowany w rekrutację robotników, zaopatrywanie ich w japońskie produkty i transfer pieniędzy z Hawajów do Japonii.

32 Y. Ichioka, op. cit., s. 45.
} 
początku XX w. ${ }^{33}$ Wizerunek Hawajów w Japonii, oprócz opowieści i listów krewnych i znajomych przebywających na Hawajach, kształtowały także książki, prasa i przewodniki. W efekcie Japończycy bardzo chętnie emigrowali na Hawaje, także wówczas, kiedy wbrew pierwotnej umowie musieli partycypować w kosztach podróży ${ }^{34}$.

Pokusa zarobienia stosunkowo dużej ilości pieniędzy była najwidoczniej na tyle silna, że przełamywała strach przed wyjazdem i podjęciem ciężkiej pracy na plantacjach. Dzień po dniu wyznaczała ona rytm życia pracowników. Już o piątej rano wszystkich budził dźwięk syreny. Po śniadaniu, o godzinie 5:30 miała miejsce zbiórka, na której robotników łączono w brygady i wyznaczano im zadania. Po niej następował wymarsz lub wyjazd do pracy. Rozpoczynała się ona o godzinie 6 i trwała do 16:30. Robotnikom należała się półgodzinna przerwa. Pracowano pod czujnym i bezwzględnym okiem znienawidzonych nadzorców (tzw. lunas). Po powrocie do domu pracownicy kąpali się i spożywali kolację. O godzinie 20 kolejna syrena wyznaczała koniec dnia. Pół godziny później wszystkie światła musiały być zgaszone ${ }^{35}$.

Dla wielu Japończyków praca na plantacjach była traumatycznym doświadczeniem. Znalazło ono odzwierciedlenie w popularnych pośród nich piosenkach ludowych zwanych holehole bushi. Duża część tych utworów opisywała trud życia na Hawajach, pracy na plantacjach czy tęsknotę za rodziną i ojczyzną. Wyrażały one rozgoryczenie robotników i ich rozczarowanie Hawajami, których obraz przed przybyciem najwidoczniej odbiegał od tego co zastali na miejscu. Wymownym przykładem tych uczuć jest poniższa piosenka:

$$
\begin{aligned}
& \text { Hawaje, Hawaje } \\
& \text { Ale kiedy przybyłem } \\
& \text { To co zobaczyłem } \\
& \text { Było piekłem } \\
& \text { Szef był szatanem } \\
& \text { Lunas } \\
& \text { Jego pomocnikami }{ }^{36}
\end{aligned}
$$

\footnotetext{
33 Y. Yoshida, Sources and Causes of Japanese Emigration, „Annals of the American Academy of Political and Social Science" 1909, t. 34, nr 2, s. 157-167.

34 Począwszy od piątego transportu, koszt podróży statkiem, ok. 70 dolarów, musiał być przez robotników zwrócony ratalnie w wysokości 6 dolarów miesięcznie. Potrącano im także z pensji po 35 centów na utrzymanie tłumaczy, inspektorów. Ustalenia te były następnie kilkakrotnie zmieniane. H. Conroy, op. cit., s. 106-109.

35 R. Takaki, Pau Hana: Plantation Life and Labor in Hawaii, 1835-1920, Honolulu 1985 [1983], s. $57-58 ; 87-91$.

36 Ibidem, s. 88. G. Okihiro przytacza nieco inną wersję tej samej piosenki: „Wonderful Hawaii, or so I heard / One look and it seems like Hell / The Manager's the Devil and / His lunas are demons”. G. Okihiro, Cane Fires: The Anti-Japanese Movement in Hawaii, 1865-1945, Phiadelphia 1991, s. 34. Najszerzej o holehole bushi: F. Odo, Voices from the Cane Fields. Folksongs from Japanese Immigrant Workers in Hawai'i, New York 2013, szczególnie rozdział trzeci.
} 
Teoretycznie Japończycy powinni znajdować się w lepszym położeniu niż robotnicy innych narodowości. Stało za nimi rosnące w siłę państwo japońskie, a dzięki konwencji mieli zapewnione wsparcie ze strony japońskich inspektorów, tłumaczy i lekarzy. Urzędnicy ci byli skupieni w specjalnym biurze kierowanym przez Joji Nakayamę, który przybył na Hawaje z pierwszą grupą imigrantów w 1885 r. Choć utrzymywani z pensji robotników, często służyli pomocą nie im, lecz plantatorom. Dla samego Nakayamy - który w przeciwieństwie do współpracowników był opłacany przez Hawaje - opieka nad imigrantami była dochodowym biznesem. Początkowo zarabiał 100 dolarów miesięcznie, następnie 250 dolarów, by ostatecznie otrzymywać aż 6 tys. dolarów rocznie. Za usługi plantatorzy wynagradzali go sowicie. Kiedy w 1892 r. pomógł wypracować porozumienie w sprawie obniżki wynagrodzeń robotników z 15 do 12,5 dolarów, wręczyli mu nagrodę w wysokości 2 tys. dolarów, a także przyznali dodatek do pensji w wysokości 200 dolarów miesięcznie, który miał być wypłacony za okres jednego roku wstecz ${ }^{37}$.

W walce o poprawę warunków pracy Japończycy uciekali się do strajków. Uczestniczyła w nich jednak ograniczona liczba robotników - w maju $1890 \mathrm{r}$. jednym z największych ok. 400 - i to na ogół pracujących na jednej plantacji ${ }^{38}$. W rezultacie nie mogły one zmusić plantatorów do poważniejszych ustępstw, ani tym bardziej gruntownie zmienić położenia robotników. Protesty te można uznać za zapowiedź potężnych strajków z pierwszych dekad XX w., które wstrząsnęły gospodarką Hawajów i przyniosły plantatorom znaczne straty.

Choć większość japońskich robotników wyjeżdżała na Hawaje z zamiarem zarobienia dużej ilości pieniędzy i powrotu do ojczyzny, to po przepracowaniu 3-letniego kontraktu spora część z nich decydowała się na pozostanie na plantacjach. 75\% robotników kontraktowych przybyłych na Hawaje w latach 1885-1890 wróciło do Japonii lub wyjechało do Stanów Zjednoczonych ${ }^{39}$. Zatem co czwarty Japończyk zdecydował się na pozostanie na Hawajach. Nawet jeżeli mała grupa spośród nich po przepracowaniu kontraktu przeniosła się do miast, oznacza to, że kilka tysięcy japońskich robotników chciało kontynuować pracę na plantacji. Najwidoczniej nie każdy identyfikował się z wizerunkiem Hawajów przedstawianym przez piosenki lub był zdania, że praca na plantacji zapewnia wyższy poziom życia niż Japonia. Z pewnością wśród tych, którzy pozostali na Hawajach, byli tacy, którym po prostu nie udało się zebrać w ciągu trzech lat planowanej kwoty. Setki osób, które po wygaśnięciu kontraktu przeniosły się na Zachodnie Wybrzeże Stanów Zjednoczonych, z powodu wzrostu antyjapońskich nastrojów w tamtejszym społeczeństwie, bardzo szybko stały się dla Tokio źródłem kłopo-

37 G. Okihiro, op. cit., s. 25-26.

38 Ibidem, s. 41-42.

39 E.C. Nordyke, op. cit., s. 64. 
tów. Na miejsce wyjeżdzających przybywali ich rodacy. W Japonii nie brakowało chętnych do wyjazdu do pracy na plantacjach. Kraj ten bardzo szybko stał się dla plantatorów niezastąpionym źródłem siły roboczej. Już w 1892 r. 13 tys. Japończyków stanowiło $63 \%$ wszystkich robotników na hawajskich plantacjach ${ }^{40}$.

Zwróciło to uwagę plantatorów na kwestię, która już wcześniej była uwzględniana przez część hawajskich polityków i w znacznej mierze leżała u podstaw zabiegów królestwa o japońskich imigrantów. Przez pierwsze lata imigracji plantatorzy byli zadowoleni z Japończyków. W 1889 r. organ prasowy Planters Labor and Supply Company, „The Planters' Monthly”, nie tylko cieszył się z niskich kosztów ich sprowadzania, ale także stwierdzono w nim, że „chętnie uczą się angielskiego języka i zwyczajów, są dobrymi pracownikami w domach, farmach i plantacjach", a ponadto są oszczędni ${ }^{41}$. Następnie plantatorzy dostrzegli jednak, że zbytnie uzależnienie od robotników jednej narodowości niesie ze sobą ryzyko ich wystąpienia przeciwko pracodawcom. W rezultacie większą uwagę zaczęli przykładać do dywersyfikacji krajów pochodzenia pracowników. W realizacji polityki divide et impera posługiwali się również wieloma innymi narzędziami. Należało do nich różnicowanie zarobków - Japończycy zarabiali nieco mniej niż Chińczycy, ogół Azjatów zaś znacznie mniej niż biali. Na Hawaje sprowadzano więcej robotników niż potrzebowano, po ty by obniżyć pensje i bardziej uzależnić ich od pracodawców. Dla robotników, których kontrakty wygasły przygotowano nowe formy pracy: akordową, opartą na kontrakcie długoterminowym i opartą na kontrakcie krótkoterminowym. Ich intencją było wzmocnienie poczucia identyfikacji z własną grupą etniczną, zamiast identyfikacji i solidarności z robotnikami innych narodowości, czyli utrzymanie segregacji rasowej na plantacjach ${ }^{42}$. Plantatorzy uciekali się też do przemocy, a nawet morderstw. Przypuszczalnie taki los spotkał działacza na rzecz praw japońskich robotników Hiroshiego Goto. W październiku 1889 r. został on powieszony na słupie telefonicznym. Winnym morderstwa uznano kilku lunas, którzy uniknęli kary opuszczając Hawaje podczas oczekiwania na rozpatrzenie ich odwołania od wyroku ${ }^{43}$.

Na Hawajach masowa imigracja japońska zbiegła się w czasie z intensyfikacją walki pomiędzy królem i jego politycznymi sojusznikami, w tym premierem Gibsonem, a Amerykanami i Europejczykami, którzy dążyli do ściślejszego powiązania ze Stanami Zjednoczonymi i zabezpieczenia własnych interesów. Działania Kalakaui, który chciał zachowania pełnej niepodległości Hawajów i przywrócenia władzy jego rdzennych mieszkańców podkopywały pozycję białych elit. Uwidoczniło się to podczas rozmów nad przedłużeniem traktatu o wzajemności

40 R. Takaki, op. cit., s. 28.

41 A. W. Lind, Hawaii's People, Honolulu 1980, s. 35.

42 J. M. Liu, Race, Ethnicity, and the Sugar Plantation System: Asian Labor in Hawaii, 1850

to 1900, [w:] Labor Immigration..., s. 187-210.

43 G. Okihiro, op. cit., s. 35. 
ze Stanami Zjednoczonymi. Waszyngton był gotów przedłużyć go na kilka lat, ale pod warunkiem, że obejmie on prawo do utworzenia stałej bazy marynarki wojennej na wyspie Oahu. Król był temu przeciwny, ale plantatorzy potrzebowali bezcłowego dostępu do amerykańskiego rynku. Z rywalizacji zwycięsko wyszli ci drudzy. W 1887 r. Kalakaua zdymisjonował Gibsona i podpisał konstytucję, która drastycznie ograniczała jego prerogatywy. Wkrótce po tym traktat o wzajemności został zawarty ${ }^{44}$.

Nowa konstytucja Hawajów, od sposobu jej wprowadzenia znana jako Bayonet Constitution determinowała przyszłość imigrantów z Japonii na Hawajach, gdyż całkowicie pozbawiała ich wpływu na bieg wydarzeń politycznych. Nie było by w tym nic zadziwiającego czy budzącego sprzeciw - byli oni przecież tymczasowymi robotnikami - gdyby nie fakt, iż Portugalczycy, również będący robotnikami na plantacjach uzyskali prawo wyborcze. Był to rezultat manewru zastosowanego przez białe elity. Prawo wyborcze zostało zarezerwowane dla mężczyzn pochodzenia hawajskiego, amerykańskiego i europejskiego, spełniających kryteria wieku, umiejętności czytania i czasu zamieszkiwania na Hawajach oraz w przypadku głosowania do wyższej izby legislatury dochodu i majątku. Od tego czasu, nie trzeba było być obywatelem, by posiadać prawo wyborcze, zarazem nie wszyscy obywatele spełniali warunki otrzymania prawa głosowania. Była to kuriozalna sytuacja, gdyż wykluczała wielu obywateli hawajskich, w tym naturalizowanych Chińczyków i Japończyków, a umożliwiała wzięcie udziału w wyborach cudzoziemcom ${ }^{45}$.

Takie rozwiązanie było uzasadnione interesami białych elit. Gdyby prawo wyborcze ograniczono do obywateli, ze względu na liczebność białych, ich wpływ na wydarzenia w państwie zostałby ograniczony ${ }^{46}$. Gdyby zaś nie zastosowano kryterium etnicznego duży wpływ na bieg wydarzeń w państwie uzyskaliby azjatyccy robotnicy, którzy stanowili znaczny i dynamicznie zwiększający się odsetek mieszkańców królestwa. Podczas gdy w 1884 r. doliczono się w nim 116 Japończyków, w 1890 r. było ich 12610 . W tym samym roku na Hawajach mieszkało ponad 16 tys. Chińczyków. Razem stanowili więc jedną trzecią z 90 tys. mieszkańców państwa ${ }^{47}$.

Tokio protestowało przeciwko dyskryminacji Japończyków wprowadzonej na mocy konstytucji z $1887 \mathrm{r}$. Hawaje przed posądzaniem o dyskryminację broniły się bardzo zręcznie, argumentując, że japońska polityka emigracyjna sprawiała, że status poddanych cesarza Meiji były odmienny od pozostałych imigrantów ${ }^{48}$. Nie ulega wątpliwości, że była to jedynie wymówka, ale jej siła polegała na

44 W. H. Morgan, op. cit., s. 24-26.

45 J. M. Van Dyke, op. cit., s. 145-147.

46 Ibidem, s. 139-140, 146.

47 E. Nordyke, op. cit., s. 178-179, tab. 3-1.

48 H. Conroy, op. cit., s. 139-140, 151, przyp. 37. 
pokryciu w faktach. Rząd japoński dążył do podporządkowania i kontrolowania emigrantów, którym nieustannie przypominano, że powinni godnie reprezentować ojczyznę za granicą. Emigrujących zaopatrywano w specjalne instrukcje wzywające do prowadzenia właściwego trybu życia. W jednej z nich, sygnowanej nazwiskiem gubernatora prefektury Hiroshima, Mikiego Nabeshimy, już w pierwszym punkcie wzywano „pamiętajcie, że jesteście poddanymi Imperium japońskiego i nigdy nie przynoście wstydu ojczyźnie haniebnymi czynami”49.

Wydarzenia następnych lat sprawiły, że imigracja japońska na Hawaje stała się jednym z ważniejszych zagadnień polityki Tokio. W styczniu 1893 r. w odpowiedzi na podjęte przez królową Lili'uokalani działania mające na celu przywrócenie pełni władzy monarszej, haole przeprowadzili zamach stanu, przejęli władzę i wystosowali do Waszyngtonu apel o aneksję. Wpłynął on w ostatnich tygodniach prezydentury republikanina Benjamina Harrisona, który skierował traktat o aneksji do Kongresu. Jednak jego następca, przeciwnik aneksji Hawajów demokrata Grover Cleveland wycofał go. Był on zwolennikiem „miękkiej” polityki USA wobec archipelagu, podobnie jak jego sekretarz stanu Walter Quentin Gresham, który uważał, że amerykańskie wpływy polityczne i gospodarcze były na Hawajach zagwarantowane, nie było więc potrzeby stwarzać sobie problemów aneksją ${ }^{50}$. Wobec nieprzejednanego stanowiska Clevelanda, który nawet próbował restytuować władzę Lili'uokalani, haole zdecydowali się na proklamowanie Republiki Hawajów. Wybrali do tego bardzo symboliczną datę 4 lipca 1894 r., rocznicę proklamowania niepodległości przez Stany Zjednoczone.

Likwidacja monarchii na Hawajach nie spotkała się z życzliwym przyjęciem w Tokio. Japonia zaprotestowała, oficjalnie z powodu obaw o los japońskich mieszkańców archipelagu, których prawa były zagwarantowane na mocy porozumienia z królestwem. Do Honolulu skierowano krążownik „Naniwa”, który dołączył do przebywającego tam okrętu „Kongo”. Formalnie stosunki ich załóg z Amerykanami służącymi na zacumowanym w tym samym porcie USS „Boston” były poprawne. Jednak na Hawajach podejrzliwość wobec Japończyków była bardzo duża, a jej owocem były plotki o ich wrogich intencjach wobec nowych władz. Zgodnie z jedną z nich „Naniwa” miała przytransportować broń dla japońskich mieszkańców Hawajów, spośród których część miała być w przeszłości żołnierzami. Wbrew tego typu podgrzewającym atmosferę plotkom rozpowszechnianym przez prasę, do konfrontacji amerykańsko-japońskiej nie doszło, a zmiana polityki USA wobec Hawajów spowodowana objęciem władzy przez Clevelanda uspokoiła sytuację ${ }^{51}$. Protest Japonii nie był czymś zupełnie nieprzewidzianym.

\footnotetext{
49 Y. Kimura, Japanese Immigrants in Hawaii, Honolulu 1988, s. 5.

50 W. LaFeber, The New Empire. An Interpretation of American Expansion, 1860-1898, Ithaca and London 1969, s. 203-206.

51 W. L. Neumann, America Encounters Japan. From Perry to MacArthur, Baltimore 1963, s. $112-113$.
} 
$\mathrm{Z}$ roku na rok wzrastała ona $\mathrm{w}$ siłę i przejawiała ambicje dołączenia do grona ówczesnych potęg. Nie mogła zatem zadowolić się rolą dostarczyciela taniej siły roboczej, lecz chciała mieć realny wpływ na bieg wydarzeń na Hawajach.

Dla wielu haole skala imigracji japońskiej, czy wręcz ,inwazji” i stanowisko Tokio było dowodem zaplanowanej i systematycznej kampanii na rzecz przemiany Hawajów w japońską kolonię ${ }^{52}$. Dla japońskiej diaspory natomiast, definitywne przejęcie władzy przez białą elitę, było przypieczętowaniem ich losu jako mieszkańców drugiej kategorii. Utrzymano bowiem w mocy przepisy prawne, uniemożliwiające Japończykom uzyskanie prawa wyborczego.

Niemal równocześnie z proklamowaniem na Hawajach republiki nastąpił tam kres dotychczasowego systemu imigracji. Motywy odejścia od niego nie do końca są jasne. Poza względami politycznymi, pewną rolę mogły odegrać finanse państwa. Być może rząd Hawajów chciał pozbyć się kosztów związanych z podróżą Japończyków, zwłaszcza, że od pewnego czasu poszukiwał dla nich alternatywy. W tym przypadku historia zatoczyła koło, ponieważ wybór padł na Chińczyków, z których imigracji przed laty zrezygnowano decydując się na sprowadzenie Japończyków. Być może liczono na to, że pozbawiona wsparcia rządu hawajskiego imigracja japońska stanie się nieopłacalna i w sposób naturalny zostanie zastąpiona przez chińską ${ }^{53}$. Jeżeli rzeczywiście tak było, kalkulacje te były błędne. Rolę japońskiego rządu przejęły japońskie kompanie emigracyjne, które z rekrutacji i transportu robotników na Hawaje uczyniły dochodowy biznes. Na tyle zyskowny, że w jego działalność zaangażowali się m.in. Jijo Nakayama, który opuścił Hawaje i były poseł w Waszyngtonie Gozo Tateno ${ }^{54}$.

Warto w tym miejscu pochylić się nad formułowanymi pod adresem Japonii zarzutami o próby celowego doprowadzenia do podboju archipelagu przez imigrację. Jeżeli byłyby one słuszne, oznaczałoby to, że w ten „spisek” zaangażowani byli także plantatorzy i konsul Irwin. Działania Irwina sugerują, że jego stosunek wobec zaopatrywania Hawajów w japońskich robotników był czysto biznesowy, a pozycja konsula była przede wszystkim przepustką do zdobycia pieniędzy ${ }^{55}$. Rozdźwięk pomiędzy plantatorami a rządem hawajskim spowodowany był balansowaniem pomiędzy potrzebą zdobycia robotników potrzebnych do ekspansji, a sprowadzeniem ich liczby na tyle niedużej, i z takiego kraju, by nie stanowili zagrożenia dla interesów państwa białej oligarchii ${ }^{56}$.

\footnotetext{
52 Zob. oświadczenie Volneya V. Ashforda, Honolulu, 8 III 1893, Foreign Relations of the United States, 1894, Affairs in Hawaii, Washington D.C. 1895, s. 680.

53 Por. H. Conroy, op. cit., s. 161.

54 O kompaniach emigracyjnych zob. A. T. Moriyama, Imingaisha: Japanese Emigration Companies and Hawaii, 1894-1908, Honolulu 1985.

55 Irwin otrzymywał pieniądze za każdego robotnika kontraktowego sprowadzonego na Hawaje.

56 Por. A. T. Moriyama, Imingaisha..., s. 98.
} 
Problem ten był obecny przez cały okres istnienia republiki na Hawajach. Celem rządu było zachowanie zagrożonej, jego zdaniem, dominacji anglosaskiej. W tym celu dążył do ograniczenia imigracji japońskiej i zwiększenia liczby imigrantów pochodzących z innych państw. Najbardziej pożądanym było oczywiście sprowadzenie białych robotników. Jednak w praktyce wszystkie plany i działania rządu okazały się zbyt trudne do wykonania. Nie udało się pozyskać większej liczby imigrantów z Portugalii, Niemiec czy Kalifornii. Z tego powodu rozmyślano nawet nad sprowadzeniem ludności czarnoskórej z amerykańskiego Południa. Pojawiły się również pomysły przyciągnięcia ludności białej przez zmianę systemu plantacyjnego na umożliwiający robotnikom większe partycypowanie w zyskach (sharecropping) lub utworzenie grupy drobnych niezależnych rolników. W celu zmiany niekorzystnej dla białych, struktury demograficznej republiki rząd powiązał imigrację Japończyków ze sprowadzeniem białych w wysokości $20 \%$ jej liczebności. W końcu, nie mogąc w żaden sposób pozyskać białych robotników opowiedział się za nowymi proporcjami imigrantów: 2/3 Chińczyków i 1/3 Japończyków. Takie rozwiązanie również nie mogło zatrzymać napływu Japończyków na Hawaje. Dzięki odpowiedniej interpretacji traktatu japońsko-hawajskiego z 1871 r. kompanie emigracyjne doprowadziły do pojawienia się na Hawajach nowej kategorii imigrantów niezwiązanych kontraktem. Zgodnie z tą interpretacją na Hawaje mógł przybyć każdy Japończyk (za wyjątkiem pewnych szczególnych przypadków jak osoby chore psychicznie, cierpiące na choroby zakaźne itp.). Wprowadzenie przez rząd Republiki Hawajów nowego prawa wymagającego posiadania przez tych „wolnych” imigrantów 50 dolarów (100 jenów), było obchodzone na różne sposoby, np. pożyczanie zainteresowanym tych pieniędzy przez kompanie emigracyjne ${ }^{57}$.

Rząd Republiki Hawajów próbował na różne sposoby przeciwdziałać napływowi Japończyków. W rezultacie ścisłego egzekwowania przepisów odmówiono prawa pobytu i odesłano do Japonii setki imigrantów. Te działania wiosną $1897 \mathrm{r}$. doprowadziły do sporu dyplomatycznego pomiędzy Honolulu a Tokio. Politycy japońscy zdawali sobie sprawę z tego, że może on przemienić się w znacznie poważniejszy dotyczący przyszłości Hawajów, którego stroną będą Stany Zjednoczone. Złożenie protestu przeciwko polityce imigracyjnej Hawajów nie podlegało dyskusji, rozbieżności pojawiły się jedynie w kwestii sposobu jego przeprowadzenia. Ostatecznie japoński minister spraw zagranicznych Shigenobu Okuma zdecydował się na wzmocnienie zajętego stanowiska przez ponowne wysłanie na Hawaje krążownika „Naniwa”. Była to odpowiedź na wojownicze nastroje części społeczeństwa japońskiego. Miał także nadzieję, że ta demonstracja sprawi, że rząd republiki zdecyduje się na zmianę stanowiska w sprawie imigracji japońskiej, wypłaci odszkodowanie za niewpuszczenie imigrantów i jednocześnie

57 Politykę imigracyjną Republiki Hawajów analizuje W. A. Russ, Jr., Hawaiian Labor and Immigration Problems Before Annexation, „The Journal of Modern History” 1943, t. 15, nr 3, s. 207-222. 
umożliwi utrzymanie Stanów Zjednoczonych z dala od trwającego sporu. Na więcej nie chciał i nie mógł sobie pozwolić, oficjalnie utrzymywał zaś, że jego celem jest ochrona Japończyków na Hawajach ${ }^{58}$.

Podstawowym, długofalowym celem Okumy było zachowanie dotychczasowego status quo na Pacyfiku. Jednak zastosowane przez niego środki sprawiły, że efekt był zupełnie odwrotny od zamierzonego. Polityka Japonii była korzystna dla zwolenników aneksji Hawajów przez Stany Zjednoczone. Przedstawiali ją jako dowód wrogich zamiarów azjatyckiego mocarstwa względem archipelagu. W rezultacie, za przyłączeniem Hawajów do USA opowiedzieli się m.in. sekretarz marynarki John Davis Long59 i W. McKinley. Prezydent na początku czerwca, podczas rozmowy z przewodniczącym senackiej Komisji Spraw Zagranicznych miał powiedzieć, że Japonia dąży do podboju Hawajów przez imigrację, a bezczynność doprowadzi do kolejnej rewolucji, skutkującej przejęciem władzy przez Japończyków ${ }^{60}$. By temu zapobiec McKinley podjął decyzję o aneksji Hawajów. Stosowny traktat podpisano 16 czerwca 1897. Ponieważ był on równoznaczny z przekreśleniem praw nabytych przez Japończyków na mocy układów zawartych przez Japonię z Hawajami oraz zmieniał na niekorzyść Japonii układ sił na Pacyfiku Tokio zaprotestowało. Na japońsko-hawajski spór imigracyjny nałożył się japońsko-amerykański konflikt o polityczną przyszłość archipelagu.

Polityka Okumy nie przyniosła rezultatu, ale i tak wykazał się on znacznie większym zrozumieniem sytuacji międzynarodowej niż poseł Japonii w Waszyngtonie Toru Hoshi, który zaproponował wysłanie floty na Hawaje w celu ich okupacji. To lekkomyślne remedium na aneksję archipelagu przez Stany Zjednoczone zostało przez Okumę rzecz jasna odrzucone ${ }^{61}$. Szef Gaimusho wiedział, że jego urzeczywistnienie byłoby równoznaczne z deklaracją wojny. Jej rezultat był trudny do przewidzenia. Mocarstwa europejskie pozostałyby w najlepszym razie neutralne, za to bardzo prawdopodobne, że wykorzystałyby nieobecność Japonii w rozgrywce mocarstw na Dalekim Wschodzie do poszerzenia swoich wpływów. Okuma był zdania, że kwestia imigracji w porównaniu z zagrożeniem Korei przez rosyjską ekspansję miała drugorzędne znaczenie.

\footnotetext{
58 Okuma do Shimamury, 19 IV 1897, Nihon Gaiko Bunsho (dalej: NGB), 1897, Tokyo 1954, s. 719-723. Okuma do Hoshiego, 17 IV 1897, ibidem, s. 958; opinia amerykańskiego posła w Tokio: Dunn do Shermana, 12 IV 1897, National Archives and Records Administration, General Records of the Department of State, Record Group 59, Despatches from U.S. Ministers to Japan, 1855-1906, M133, roll 70.

59 Roosevelt do Mahana, 3 V 1897 r., The Letters of Theodore Roosevelt, t. I, The Years of Preparation, 1868-1898, selected and edited by E. E. Morison, Cambridge 1951, s. 608.

60 G. F. Hoar, Autobiography of Seventy Years, t. II, New York 1903, s. 307-308.

61 Hoshi do Okumy, 17 VI 1897, NGB, 1897, s. 978; Okuma do Hoshiego, 19 VI 1897, ibidem, s. 985-986.
} 
To właśnie pod wpływem narastania rywalizacji mocarstw w Azji Tokio zdecydowało się zakończyć spór z USA i skupić swoją uwagę na poczynaniach Rosji. Petersburg wyraźnie pokazał, że nie liczy się z Japonią wprowadzając swoją flotę na początku grudnia 1897 r. do chińskiego portu Lushun (Port Arthur), którego 2 lata wcześniej została ona pozbawiona przez „potrójną interwencję"62.

Pogodzenie się Japonii z aneksją Hawajów przez Stany Zjednoczone nie oznaczało kresu sporu imigracyjnego z rządem wciąż istniejącej republiki. Wprawdzie Tokio przystało na złożoną przez Honolulu propozycję oddania go pod arbitraż ${ }^{63}$, jednak sprawa utknęła w martwym punkcie. Do jego rozwiązania, podobnie jak w przypadku sporu o aneksję Hawajów, przyczyniła się geopolityka. Wojna z Hiszpanią stworzyła atmosferę sprzyjającą przyłączeniu archipelagu do USA ${ }^{64}$. McKinley chciał jednak, by spór japońsko-hawajski został rozwiązany zanim to nastąpi. Rząd republiki, pozbawiony innego wyjścia zdecydował się na wypłatę Japonii 75 tys. dolarów (150 tys. jenów) odszkodowania ${ }^{65}$.

Przejęcie zwierzchnictwa nad Hawajami przez USA miało bardzo duże znaczenie dla imigracji azjatyckiej. Paradoksalnie zastosowanie amerykańskiego prawa wprowadzało zmiany, przed którymi rząd republiki bronił się. Ponieważ od 1882 r. amerykańskie prawo zakazywało imigracji Chińczyków, jego wdrożenie na Hawajach sprawiało, że jedynym źródłem robotników dla plantacji, przynajmniej do czasu znalezienia innego, stali się Japończycy. Od $1891 \mathrm{r}$. amerykański system prawny penalizował imigrację kontraktową, co oznaczało, że jedynymi imigrantami-robotnikami mogli być imigranci „wolni”. Obowiązujące w USA jus soli przyznawało obywatelstwo wszystkim osobom urodzonym na obszarze państwa amerykańskiego, co było równoznaczne z pojawieniem się grupy Japończyków obywateli amerykańskich i wyborców. Była to wówczas mała grupa, i z racji wieku niemogąca korzystać z nowo uzyskanych praw, jednak w dalszej perspektywie pojawiła się nowa konkurencja dla władzy politycznej haole.

\footnotetext{
62 Na początku następnego roku Rosja wydzierżawiła ten port. Zob. np. M. Kajima, The Emergence of Japan as a World Power, 1895-1925, Tokyo 1968, s. 57-62. Japonia otrzymała od Chin półwysep Liaodong wraz z Lushunem na mocy traktatu pokojowego zawartego w kwietniu $1895 \mathrm{r}$. Już w następnym miesiącu zwróciła go pod presją Rosji, Francji i Niemiec, które były przeciwne usadowieniu się Japonii w Chinach.

${ }^{63}$ Okuma do Shimamury, 4 VIII 1897, NGB 1897, s. 835-837; Shimamura do Coopera, 11 VIII 1907, ibidem, s. 855; 16 VIII 1897, ibidem, s. 838.

64 Traktat o aneksji wymagał ratyfikacji przez senat, do czego wymagane było $2 / 3$ głosów. Takiej liczby nie udało się jednak zebrać. W 1898 r. zdecydowano się na przeprowadzenie aneksji przez rezolucję zwykłą większością głosów.

65 Hoshi do Okumy, 7 VII 1898, NGB 1898.2, Tokyo 1954, s. 174-175; Cooper do Hirai, ibidem, s. $186-188$.
} 
Mimo tych niekorzystnych z punktu widzenia białej elity Hawajów zmian, „inwazja” japońska na krótko przestała być dla tej grupy najważniejszym zagrożeniem. Najważniejsza zmiana - wejście w skład Stanów Zjednoczonych - była gwarancją jej pozycji. Ograniczenia imigracyjne zostały anulowane, a plantatorzy wykorzystując krótki okres przed wprowadzeniem na Hawajach w 1900 r. amerykańskiego prawa masowo sprowadzali robotników kontraktowych z Japonii. Podczas gdy w 1896 r. na Hawajach mieszkało 24 tys. Japończyków, w 1900 r. już 61 tys., którzy stanowili 22,4\% wszystkich mieszkańców terytorium Hawajów ${ }^{66}$.

Nie znaczyło to jednak, że biali mieszkańcy Hawajów jak i politycy przestali się obawiać konsekwencji imigracji japońskiej. Jej skala sprawiała, że nie brakowało zwolenników poglądu o japonizacji archipelagu. Już w 1902 r. w raporcie komisarza ds. imigracji stwierdzono, że imigracyjna polityka laissez faire doprowadzi do uczynienia go „,praktycznie japońskim” w ciągu kilku lat ${ }^{67}$. Tak się nigdy nie stało, ale Japończycy przez długie dekady byli największą grupą etniczną na Hawajach. Zgodnie ze spisami powszechnymi przeprowadzanymi w USA co dziesięć lat, najwyższy odsetek mieszkańców - 42,7\% - stanowili w 1930 r. Ich liczebność była jednym z powodów, dla których Hawaje aż do 1959 r. nie zostały przyjęte do Unii jako stan. Dla wielu sytuacja, w której niemal połowa mieszkańców miała japońskie korzenie zdawała się być koszmarem ${ }^{68}$.

Większość japońskich polityków i wojskowych oraz społeczeństwa tego kraju zaakceptowała aneksję Hawajów przez Stany Zjednoczone. Mniejszość, jak późniejszy admirał, minister marynarki i premier Kanji Kato, który w 1893 r. służył na „Naniwie”, uważała, że rywalizację można było poprowadzić tak, by przynajmniej zabezpieczyć neutralność Hawajów ${ }^{69}$. Niemniej archipelag, jako pierwsze miejsce, do którego emigrowali Japończycy, był mieszkańcom Japonii bliski, co przyczyniło się do włączenia go w skład lansowanej przez Tokio podczas II wojny światowej Strefy Wspólnego Dobrobytu ${ }^{70}$.

Spór hawajsko-japoński dotyczący imigracji, do którego następnie włączyły się Stany Zjednoczone, był zapowiedzią konfliktów na tym tle, które w pierwszych trzech dekadach XX w. w znaczącym stopniu przyczyniły się do pogorszenia stosunków japońsko-amerykańskich. Uwidocznił też pewne elementy, które

\footnotetext{
${ }^{66}$ H. Conroy, op. cit., s. 196.

67 A W. Lind, Hawaii's Japanese. An Experiment in Democracy, Princeton 1946, s. 13.

68 Demokratyczny kongresmen z Missisipi John Rankin odnosząc się do bohatera filmowego, detektywa Mr. Moto, miał powiedzieć w 1937 r.: „Mah Gawd, if we give them folks statehood we're lahkley to have a senator called Moto". Cyt. za R. Daniels, Guarding the Golden Door. American Immigration Policy and Immigrants since 1882, New York 2005 [2004], s. 38.

69 Opinia Kato zob. I. Gow, Military Intervention in Pre-War Japanese Politics: Admiral Kato Kanji and the 'Washington System', New York 2005, s. 41.

70 J. J. Stephan, Hawaii Under the Rising Sun. Japan's Plan for Conquest After Pearl Harbor, Honolulu 1984, rozdz. IX.
} 
odpowiednio zinterpretowane mogły służyć Amerykanom za wskazówki rozwiązywania sporów imigracyjnych z Japonią. Najważniejszy z nich jest chyba taki, że Tokio było wyczulone na wszelką dyskryminację i protestowało przeciw niej zdecydowanie i konsekwentnie. Japonia była jednak przy tym elastyczna i skłonna do ustępstw, szczególnie w sytuacji zagrożenia istotniejszych z jej punktu widzenia interesów. Najlepszy tego dowód Waszyngton otrzymał w 1902 r., gdy Japonia zawarła sojusz z Wielką Brytanią, pomimo że Australia (jej dominium) uchwaliła rok wcześniej ustawę dyskryminującą imigrację japońską ${ }^{71}$. Nobilitujący sojusz z największym ówczesnym mocarstwem miał w oczach japońskich polityków (zresztą słusznie) rangę nieporównywalną z równouprawnieniem ich rodaków w odległych państwach.

Na mapie migracji XIX i XX w. imigracja Japończyków na Hawaje zajmuje szczególne miejsce. Była ona od samego początku ściśle powiązana ze stosunkami międzynarodowymi. Oddziaływały na nią nie tylko czynniki ekonomiczne czy społeczne, ale także polityczne, jak rywalizacja mocarstw w Azji i na Pacyfiku. Można również powiedzieć, że w krótkim czasie ruch ten stał się przeciwieństwem tego, czego oczekiwano. Miał być rozwiązaniem problemów gospodarczych Japonii i Hawajów, a stała się dla nich źródłem problemów politycznych.

\section{Immigration to Hawaii from Japan in 1885-1900}

\section{Summary}

In the first half of the 19th century the Kingdom of Hawaii was declared to be a part of the American sphere of influence. Americans and Europeans had a great influence on the country's internal and foreign policy. They built their position on agriculture, in particular on the cultivation of sugar cane. Due to the lack of local manpower, they brought to Hawaii Asians - the Chinese, and then the Japanese. The Japanese government agreed to emigration of its laborers because of various reasons, including economic problems affecting rural areas. The conditions of their work and life were strictly regulated by the immigration convention concluded in 1886. In the years 1885-1894, 29,000 people came to work on plantations under the contract system.

The proclamation of the Republic of Hawaii in 1894, which replaced the overthrown monarchy, coincided with the withdrawal of the government of this state from recruitment and importing workers from Japan. The resulting gap was filled in by Japanese emigre companies that brought not only contract workers

71 M. Willard, History of the White Australia Policy to 1920, London 1967 [1923], s. 123-125. 
but also non-contractual immigrants to Hawaii. The Government of the Republic of Hawaii considered the increased and uncontrolled inflow of the Japanese to be a threat. For this reason, it decided to limit this immigration. The refusal to let hundreds of Japanese enter Hawaii led to an immigration dispute between Tokyo and Honolulu. It contributed to the decision of the United States to annex Hawaii in 1897. Such a step evoked protests from Japan, yet, they were withdrawn at the end of the year, due to the growing competition of the powers in the Far East. The immigration dispute between Hawaii and Japan was finally resolved under the pressure from Washington in 1898, after the republic's government paid out $\$ 75,000$ compensation.

Key words: Hawaii, Japan, United States, immigration, expansion

\section{Bibliografia}

\section{Źródła archiwalne}

National Archives and Records Administration, General Records of the Department of State, Record Group 59, Despatches from U.S. Ministers to Japan, 1855-1906, M133, roll 70.

\section{Źródła publikowane}

Foreign Relations of the United States, 1894, Affairs in Hawaii, Washington D.C. 1895.

Nihon Gaiko Bunsho 1897, Tokyo 1954.

Nihon Gaiko Bunsho 1898.2, Tokyo 1954.

Treaties and Conventions, Concluded Between Empire Of Japan and Foreign Nations, Together with Regulations and Communications, 1854-1874, Tokio 1874.

The Letters of Theodore Roosevelt, t. I, The Years of Preparation, 1868-1898, selected and edited by E. E. Morison, Cambridge 1951.

\section{Autobiografia}

Hoar G. F., Autobiography of Seventy Years, t. II, New York 1903.

\section{Opracowania}

Beechert E. D., Working in Hawaii: A Labor History, Honolulu 1985.

Chang R. T., General Grant's 1879 Visit to Japan, „Monumenta Nipponica” 1969, t. 24, nr 4, s. 379-392.

Conroy H., Japanese Expansion into Hawaii, 1868-1898, San Francisco 1973 [1949]. 
Daniels R., Guarding the Golden Door. American Immigration Policy and Immigrants since 1882, New York 2005 [2004].

Gow I., Military Intervention in Pre-War Japanese Politics: Admiral Kato Kanji and the 'Washington System', New York 2005.

Hackler R. E. A., Alliance or Cession? Missing Letter from Kamehameha I to King George III of England Casts Light on 1794 Agreement, „Hawaiian Journal of History" 1986, t. 20, s. 1-14.

Ichioka Y., The Issei: The World of the First Generation Japanese Immigrants, 1885-1924, New York and London 1988.

Iriye A., Pacific Estrangement: Japanese and American Expansion, 1897-1911, Chicago 1994 [1972].

Irwin Y., Conroy H., R. W. Irwin and Systematic Immigration to Hawaii, [w:] East Across the Pacific. Historiological \& Sociological Studies of Japanese Immigration \& Assimilation, red. H. Conroy, T. S. Miyakawa, Santa Barbara and London 1972, s. 40-55.

Kajima M., The Emergence of Japan as a World Power, 1895-1925, Tokyo 1968.

Kent N. J., Hawaii: Islands under the Influence, New York 1983.

Kimura Y., Japanese Immigrants in Hawaii, Honolulu 1988.

Kotani T., Pau Hana: Plantation Life and Labor in Hawaii, 1835-1920, Honolulu 1985 [1983].

Kuykendall R. S., The Hawaiian Kingdom, t. I: 1778-1854. Foundation and Transformation, Honolulu 1965 [1938].

Kuykendall R. S., The Hawaiian Kingdom, t. 3, 1874-1893, The Kalakaua Dynasty, Honolulu 1967.

Ladenson A., The Background of the Hawaiian-Japanese Labor Convention of 1886, „Pacific Historical Review" 1940, t. 9, nr 4, s. 389-400, przedrukowane w: Kodomo no tame ni-For the Sake of the Children. The Japanese American Experience in Hawaii, red. D. Ogawa, Honolulu 1978, s. 12-19.

LaFeber W., The New Empire. An Interpretation of American Expansion, 1860-1898, Ithaca and London 1969.

Lind A. W., Hawaii's Japanese. An Experiment in Democracy, Princeton 1946.

Lind A. W., Hawaii's People, Honolulu 1980.

Liu J. M., Race, Ethnicity, and the Sugar Plantation System: Asian Labor in Hawaii, 1850 to 1900, [w:] Labor Immigration Under Capitalism. Asian Workers in the United States Before World War II, red. L. Cheng, E. Bonacich, Berkeley-Los Angeles-London 1984, s. 187-210.

Marumoto M., ,First Year” Immigrants to Hawaii \& Eugen Van Reed, [w:] East Across the Pacific. Historiological \& Sociological Studies of Japanese Immigration \& Assimilation, red. H. Conroy, T. S. Miyakawa, Santa Barbara and London 1972, s. 5-25.

Morgan W. M., Pacific Gibraltar: U.S.-Japanese Rivalry Over the Annexation of Hawai'i, 1885-1898, Annapolis 2011. 
Moriyama A. T., Imingaisha: Japanese Emigration Companies and Hawaii, 1894-1908, Honolulu 1985.

Moriyama A., The Causes of Emigration: The Background of Japanese Emigration to Hawaii, 1885-1894, [w:] Labor Immigration Under Capitalism. Asian Workers in the United States Before World War II, red. L. Cheng, E. Bonacich, Berkeley-Los Angeles-London 1984, 248-276.

Neumann W. L., America Encounters Japan. From Perry to MacArthur, Baltimore 1963.

Nish I., Japanese Foreign Policy, 1869-1942. Kasumigaseki to Miyakezaka, London and New York 2010 [1977].

Nordyke E. C., The Peopling of Hawai'i, Honolulu 1989 [1977].

Nordyke E. C., Lee R. K. C., The Chinese in Hawai'i: A Historical and Demographic Perspective, „Hawaiian Journal of History” 1989, t. 23, s. 196-216.

Odo F., Voices from the Cane Fields. Folksongs from Japanese Immigrant Workers in Hawai' $i$, New York 2013.

Okihiro G., Cane Fires: The Anti-Japanese Movement in Hawaii, 1865-1945, Philadelphia 1991.

Pałasz-Rutkowska E., Cesarz Meiji (1852-1912). Wizerunek władcy w modernizowanej Japonii, Warszawa 2012.

Pierce R. A., Georg Anton Schäffer, Russia's Man in Hawaii, 1815-1817, „Pacific Historical Review" 1963, t. 32, nr 4, s. 397-405.

J. Polit, Japońska polityka zagraniczna 1895-1945, Kraków 2015.

Russ, Jr. W. A., Hawaiian Labor and Immigration Problems Before Annexation, „The Journal of Modern History" 1943, t. 15, nr 3, s. 207-222.

Saveliev I. G., Rescuing the Prisoners of „Maria Luz”: the Meiji Government and the 'Coolie Trade', 1868-1875, [w:] Turning Points in Japanese History, red. B. Edström, London and New York 2013 [2002], s. 71-81.

Stephan J. J., Hawaii Under the Rising Sun. Japan's Plan for Conquest After Pearl Harbor, Honolulu 1984.

Stevens S. K., American Expansion in Hawaii, 1842-1898, New York 1945.

Tate M., Great Britain and the Sovereignty of Hawaii, „Pacific Historical Review” 1962, t. 31, nr 4, s. 327-348.

Trask H-K., From a Native Daughter. Colonialism and Sovereignty in Hawai’i, Honolulu 1999 [1993].

Willard M., History of the White Australia Policy to 1920, London 1967 [1923].

Van Dyke J. M., Who Owns the Crown Lands of Hawai'i?, Honolulu 2008.

Vlastos S., Opposition Movements in Early Meiji, 1868-1885, [w:] The Cambridge History of Japan, t. 5: The Nineteenth Century, red. M. B. Jansen, New York 2007 [1989], s. 367-431. 